See discussions, stats, and author profiles for this publication at: https://www.researchgate.net/publication/344165569

\title{
Enhancing State-to-State Dialogue on Internal Displacement: Current Global Fora and Future Prospects?
}

Preprint · August 2020

DOI: $10.13140 / R G \cdot 2 \cdot 2 \cdot 15121.25441$

\section{CITATIONS}

0

2 authors:

Ben Hudson

University of Exeter

2 PUBLICATIONS O CITATIONS

SEE PROFILE
READS

18

B1.5id Ní Ghráinne
National University of Ireland, Maynooth
20 PUBLICATIONS 8 CITATIONS
SEE PROFILE

Some of the authors of this publication are also working on these related projects: 


\title{
Enhancing State-to-State Dialogue on Internal Displacement: Current Global Fora and Future Prospects?

\author{
Ben Hudson \& Bríd Ní Ghráinne ${ }^{1}$
}

\begin{abstract}
August 2020
This is a pre-peer review authors' original version. A post-peer review version of this article has been accepted for publication in Refugee Survey Quarterly published by Oxford University Press.
\end{abstract}

\footnotetext{
${ }^{1}$ Dr Ben Hudson is a Lecturer in Law at the University of Exeter, UK. Dr Bríd Ní Ghráinne is Assistant Professor at Maynooth University, Ireland; Senior Researcher at the Judicial Studies Institute, Masaryk University; and Senior Researcher at the Institute of International Relations, Prague. The authors are grateful to Prof David Cantor for both his guidance and invaluable comments on an earlier draft of this article. The authors also wish to thank everyone else who contributed their input to this paper, including the anonymous reviwers for their feedback and insights.
} 


\section{INTRODUCTION}

This paper explores the potential for global platforms to facilitate State peer-to-peer learning, collaboration and mobilisation on internal displacement. As such, it is broadly interested in questions around the promotion of political will, responsibility and accountability, albeit that detailed discussions of each of these underlying concepts lies beyond its scope. The paper examines a range of global platforms where peer-to-peer dialogue and learning between States on internal displacement matters may take place, rather than focusing on the humanitarian or development architecture of the United Nations (UN) system. Firstly, given the understanding of internal displacement as a human rights concern, it examines the extent to which pertinent political fora concerned with human rights function as appropriate platforms. Secondly, given the close relationship of internal displacement and refugee issues, it explores the scope of existing refugee fora as sites or models for the discussion of internal displacement. Finally, it assesses the prospects for a dedicated global forum on internal displacement, based on incipient processes that currently exist to facilitate peer-to-peer dialogue and exchange among States on IDP issues.

\section{UN HUMAN RIGHTS PLATFORMS}

Internal displacement is often framed as a human rights issue. ${ }^{2}$ This is indeed evident in the very title of the UN IDP mandate, which has since the mid-2000s explicitly and consistently featured 'human rights'. International human rights treaty bodies (HRTBs), including those of potentially global scope such as the UN Human Rights Committee, have frequently addressed the issue of internal displacement, often as a result of complaints by IDPs of rights violations. ${ }^{3}$ However, HRTB procedures are generally not fora that facilitate inter-State dialogue, but instead involve a bilateral dialogue between the HRTB and a single Member State. Moreover, HRTBs are restricted to reviewing only those States that have ratified the treaty with which the

\footnotetext{
${ }^{2}$ B. Ní Ghráinne, Internally Displaced Persons and International Refugee Law, Oxford, Oxford University Press, 2021 (forthcoming); C. Phuong, The International Protection of Internally Displaced Persons, Cambridge, Cambridge University Press, 2005, 235. In the Inter-Agency Standing Committee (IASC) 2010 Framework on Durable Solutions for Internally Displaced Persons, human rights are explicitly identified as pivotal to the successful achievement of a durable solution - it states, at page 5, that 'A durable solution is achieved when IDPs no longer have specific assistance and protection needs that are linked to their displacement and such persons can enjoy their human rights without discrimination resulting from their displacement'.

3 D. Cantor, “'The IDP in International Law'? Developments, Debates, Prospects”, International Journal of Refugee Law, 30(2), 2018, 191-217, 200-201.
} 
particular HRTB is associated. This means that although HRTBs are in theory global, in practice their scope typically falls short of achieving this. ${ }^{4}$

In contrast, the Universal Periodic Review (UPR) can more accurately be characterised as a truly global mechanism of regular human rights review involving all UN Member States. The UPR, which is held under the auspices of the UN Human Rights Council, is intended to be 'a cooperative mechanism, based on an interactive dialogue' between Member States, 'with the full involvement of the country concerned and with consideration given to its capacity-building needs'. ${ }^{5}$ Given the UPR's intended 'universality of coverage', ${ }^{6}$ a plethora of issues are raised for discussion, largely by reviewing Member States through pre-submitted questions and/or during the interactive dialogue, or by the Member State under review in its national report. This implies that it might offer a useful platform for inter-State dialogue on internal displacement as an important human rights issue. Yet a content analysis of UPR documentation to date shows that discussion of internal displacement during the UPR process has thus far been i) unsystematic (ii) limited, and iii) resisted.

\subsection{Unsystematic}

In 2019 alone, instances of internal displacement were recorded across 145 countries and territories. ${ }^{7}$ Yet, a brief review of recent UPR cycles reveals a clear tendency towards treating internal displacement as an issue that affects only a select few Member States. This is not necessarily intentional or calculated. Instead, it is likely a consequence of the unsystematic way in which internal displacement is raised through the UPR process. ${ }^{8}$ Indeed, unless the Member State under review is voluntarily forthcoming with such information, the onus is very much on reviewing Member States to raise internal displacement as a matter of concern, often on the basis of information provided in stakeholder (for example, non-governmental organisation

\footnotetext{
${ }^{4}$ Indeed, no international human rights treaty is universally ratified, albeit that the UN Convention on the Rights of the Child falls short by only one eligible Member State, the United States of America (USA).

${ }^{5}$ General Assembly resolution 60/251, 3 April 2006, A/RES/60/251, para. 5(e).

${ }^{6}$ General Assembly resolution 60/251, 3 April 2006, A/RES/60/251, para. 5(e).

${ }^{7}$ Internal Displacement Monitoring Centre (IDMC), Global Report on Internal Displacement, Geneva, IDMC, 2020, available at: https://www.internal-displacement.org/global-report/grid2020 (last visited 3 Aug. 2020 ), 8.

${ }^{8}$ More generally, Cowan and Billaud have identified the UPR as being 'haunted by an older model of tutelage in which an enlightened West guide a backward non-West in its efforts to 'catch up' with the norms that the West has set', see J. Cowan and J. Billaud, "Between Learning and Schooling: The Politics of Human Rights Monitoring at the Universal Periodic Review", Third World Quarterly, 36(6), 2015, 1175-1190, 1187-1188.
} 
(NGO) and national human rights institution (NHRI)) reports, ${ }^{9}$ and to then follow it up across multiple UPR cycles to ensure this attention is sustained. As a result, a pertinent substantive issue can quite easily slip off the agenda, whether this be because the political will to address this issue wanes, or, alternatively, if there is a collective omission and/or an overwhelming prioritisation of other issues. This might not be such a problem if that particular substantive issue is being systematically raised elsewhere in some other peer-to-peer forum. Yet, in the case of internal displacement, there is no evidence that this is presently the case.

\subsection{Limited}

The current treatment of internal displacement within the UPR process is limited in three main ways: in respect to quantity, substance and conceptual framing. These deficiencies are illustrated by a brief analysis of the most recent UPR cycles for the three Member States with the highest total numbers of conflict and violence-induced IDPs as of 2019-end: the Syrian Arab Republic (Syria), Colombia and the Democratic Republic of Congo (DRC). What these three examples reveal is a surprising sparsity of direct references to internal displacement.

Of these three Member States, it was only in respect to Syria that Member States raised the issue of internal displacement in pre-submitted questions, albeit only by two States specifically. ${ }^{10}$ That being said, Syria itself did refer to internal displacement in its national report, ${ }^{11}$ as did Colombia in respect to IDP-related recommendations made in its previous UPR cycle. ${ }^{12}$ By contrast, the DRC national report contained no mention of internal displacement. ${ }^{13}$ Similarly, during the interactive dialogue for each State, internal displacement was mentioned only tangentially once for Colombia (by Russia), merely using IDP numbers as an indicator of the security situation; ${ }^{14}$ once for the DRC (by Chile), as an effect of continuing tribal violence, ${ }^{15}$

\footnotetext{
${ }^{9}$ A compilation of UN information report is also produced in advance. This presents State-specific findings and recommendations from, inter alia, UN HRTB and mechanisms, including Special Rapporteurs. For an analysis of the influence that stakeholder and compilation reports have on reviewing Member States' recommendations, see F. McGaughey, "The Role and Influence of Non-governmental Organisations in the Universal Periodic Review International Context and Australian Case Study", Human Rights Law Review, 17, 2017, 421-450.

${ }^{10}$ Czechia and the United Kingdom. Slovenia also mentioned forced displacement, albeit only sweepingly as a factor aggravating the risk of statelessness.

${ }^{11}$ National Report of the Syrian Arab Republic, 28 September 2016, A/HRC/WG.6/26/SYR/1.

${ }^{12}$ National Report of Colombia, 26 February 2018, A/HRC/WG.6/30/COL/1, see in particular paras 56-58.

${ }^{13}$ National Report of the Democratic Republic of the Congo, 27 February 2019, A/HRC/WG.6/33/COD/1.

${ }^{14}$ Report of the Working Group on the Universal Periodic Review - Colombia, 9 July 2018, A/HRC/39/6, para. 102.

${ }^{15}$ Report of the Working Group on the Universal Periodic Review - Democratic Republic of the Congo, 5 July 2019, A/HRC/42/5, para. 48.
} 
and once for Syria (by Ireland). ${ }^{16}$ This absence of internal displacement in the pre-submitted reports and questions and in the interactive dialogue is not merely a reflection of the wide range of issues canvassed during the UPR process, such that all receive relatively sparse attention. In respect to Colombia and the DRC, far more explicit attention is given to the rights of indigenous peoples who, while often displaced, likely form just one subset of IDPs in any given Member State.

Turning now to the UPR recommendations. Internal displacement was mentioned only once for Colombia (by Azerbaijan), in relation to IDP returns $;{ }^{17}$ four times for the DRC (by Angola, Chad, Senegal and Uganda), ${ }^{18}$ three of which concerned ratification and domestication of the Kampala Convention; and five times for Syria (by Ecuador, Holy See, Iran and Russia), ${ }^{19}$ two of which concerned return. In terms of substance, the majority of recommendations indeed concerned either IDP return or matters of formal legal process, such as the ratification and domestication of the Kampala Convention in the case of the DRC. In this sense, the recommendations are quite narrowly framed when one considers the breadth of rights impacted by internal displacement, as evidenced by the 1998 UN Guiding Principles on Internal Displacement (which themselves rarely feature in any of these UPR discussions).

Yet, while references to IDP human rights are sparse in respect to conflict and violence related displacement, when it comes to disaster-induced displacement such references are almost nonexistent. India, China and the Philippines all regularly feature within the top five Member States with the greatest number of new disaster-induced displacements per year. In 2019 alone, India experienced over five million new displacements associated with disasters, and the Philippines and China just over four million each. ${ }^{20}$ All three Member States also feature in the IDMC's top ten countries for people internally displaced by disasters as of 2019-end. ${ }^{21}$ Yet, in the most recent UPR cycles for India and China, in May 2017 and November 2018 respectively,

\footnotetext{
${ }^{16}$ Report of the Working Group on the Universal Periodic Review - Syrian Arab Republic, 27 December 2016, $\mathrm{A} / \mathrm{HRC} / 34 / 5$, para. 22.

${ }^{17}$ Report of the Working Group on the Universal Periodic Review - Colombia, 9 July 2018, A/HRC/39/6, para 120.181 .

${ }^{18}$ Report of the Working Group on the Universal Periodic Review - Democratic Republic of the Congo, 5 July 2019, A/HRC/42/5, paras. 119.264 (Angola), 119.26 (Chad), 119.24 (Senegal), and 119.25 (Uganda).

${ }^{19}$ Report of the Working Group on the Universal Periodic Review - Syrian Arab Republic, 27 December 2016, A/HRC/34/5, paras. 109.84 (Ecuador), 109.198 and 109.199 (Iran), 109.197 (Holy See), and 109.196 (Russia).

${ }^{20}$ Internal Displacement Monitoring Centre (IDMC), Global Report on Internal Displacement, Geneva, IDMC, 2020, available at: https://www.internal-displacement.org/global-report/grid2020 (last visited 3 Aug. 2020), 8.

${ }^{21}$ IDMC's estimate: 5.1 million in total $(2020,2)$.
} 
there was absolutely no mention of displacement at all. ${ }^{22}$ Similarly, in respect to the Philippines, there were only two explicit references to internal displacement in the documentation produced during its latest UPR cycle, in May 2017. One was a general comment made by Mexico during the interactive dialogue, which 'hailed... the actions to assist displaced people', ${ }^{23}$ and the other was a recommendation from Kenya calling on the Philippines to 'Develop a permanent resettlement approach for internally displaced persons'. ${ }^{24}$ This once again demonstrates a substantial lack of discussion around internal displacement. It also reveals a narrow conceptual framing of internal displacement within the UPR process, one that is, at least to a significant extent, restricted to conflict and violence induced displacement

\subsection{Resisted}

A content analysis of UPR documentation does not readily reveal the opinions or perspectives that Member States under review hold on particular lines of enquiry. While it may be tempting to deduce such insights from whether or not a Member State accepts a particular recommendation, this is a rather inconclusive metric for three main reasons. First, acceptance or rejection may be determined by the strength of wording used by the reviewing Member State - an innocuously worded recommendation is likely to be rather more palatable than one which is more pointed in its tone. Second, the extent to which a recommendation demands a Member State makes a clearly defined and measurable commitment on a specific matter is likely to have a significant bearing on how the recommendation is received - it is typically less taxing to agree to ambiguous, high-level statements; and generally much easier to 'seek to' achieve something than to 'commit to' achieving it. ${ }^{25}$ Third, it is evident that inter-State relations, between the Member State under review and reviewing Member States, play a role in whether particular recommendations are accepted or rejected. ${ }^{26}$ As an alternative, it might be plausible

\footnotetext{
${ }^{22}$ All documentation for the third UPR cycle for China is available at: https://www.ohchr.org/EN/HRBodies/UPR/Pages/CNindex.aspx (last visited 3 Aug. 2020). All documentation for the third UPR cycle for India is available at: https://www.ohchr.org/EN/HRBodies/UPR/Pages/INIndex.aspx (last visited 3 Aug. 2020).

${ }^{23}$ Report of the Working Group on the Universal Periodic Review - Philippines, 18 July 2017, A/HRC/36/12, para. 82.

${ }^{24}$ Report of the Working Group on the Universal Periodic Review - Philippines, 18 July 2017, A/HRC/36/12, para. 133.255.

${ }^{25}$ As Bueno de Mesquita observes in the context of the right to health, 'recommendations often suffer from a lack of specificity', see J. Bueno de Mesquita, "The Universal Periodic Review: A Valuable New Procedure for the Right to Health?”, Health and Human Rights Journal, 21(2), 2019, 263-277, 274.

26 As Abebe warns, 'There are ominous signs that the problem of regional block voting, which had seriously afflicted the former Commission, remains a formidable challenge to the Council's decision making process ... Regional alliance is a major force influencing the review process [the UPR]. Groups [for example, the European
} 
to argue that the lack of explicit references in UPR documentation to internal displacement, for example in the abovementioned examples of India and China, stems from a perception that the Member State under review would be hostile to such discussion, but this too would be a rather sweeping conclusion to reach on this basis alone.

Clear signs of resistance do appear, however, when reviewing the latest UPR cycle for Syria. As outlined above, five of the recommendations made in October 2016 explicitly mentioned internal displacement. In respect to three of these, the Syrian government responded saying that these 'have been implemented and details are to be found in the national report'. ${ }^{27}$ The instruction to look back to the national report indicates that, in the view of the Member State under review, this work has already been completed. It also appears rather dismissive of what is surely an objective need to indeed continue strengthening its efforts in respect to IDP assistance and durable solutions.

Aside from the recommendations, it is also instructive to look at the response of Syria, and in fact the Human Rights Council President, when challenged during the interactive dialogue. Only one explicit comment was made in respect to displacement during this portion of the review, this by Ireland, which 'condemned the atrocities committed by the Syrian Arab Republic and its allies, including the deliberate targeting of civilians, the suppression of protests, forced displacement and mass detention without trial'. ${ }^{28}$ The Syrian delegation's response was to raise a point of order, specifically that 'speakers were required... to use diplomatic language'. ${ }^{29}$ The Human Rights Council President responded by encouraging 'all

\footnotetext{
Union (EU), the African Group, the Organisation of Islamic States and the Non-Aligned Movement] never issue statements that are critical of one of their own. In fact, states belonging to similar regional groupings often make statements praising the human rights situation in the state under review', see A. Abebe, "Of Shaming and Bargaining: African States and the Universal Periodic Review of the United Nations Human Rights Council", Human Rights Law Review, 9(1), 2009, 1-35, 19. Sweeney and Saito have identified attempts by States 'friendly' with the State under review to essentially filibuster the interactive dialogue', see G. Sweeney and Y. Saito, "An NGO Assessment of the New Mechanisms of the UN Human Rights Council", Human Rights Law Review, 9(2), 2009, 203-223, 210. Bueno de Mesquita (2019) has similarly found that 'recommendations appear to be influenced by domestic and international political agendas' (274).

${ }^{27}$ Report of the Working Group on the Universal Periodic Review Addendum - Syrian Arab Republic, 13 March 2017, A/HRC/34/5/Add.1, 6 (in respect to recommendations 109.196-109.198). It is unclear from the documentation submitted by Syria whether the other two related recommendations, 109.84 and 109.199, were accepted, rejected or simply noted.

${ }^{28}$ Report of the Working Group on the Universal Periodic Review - Syrian Arab Republic, 27 December 2016, $\mathrm{A} / \mathrm{HRC} / 34 / 5$, para. 22.

${ }^{29}$ Report of the Working Group on the Universal Periodic Review - Syrian Arab Republic, 27 December 2016, A/HRC/34/5, para. 23.
} 
speakers to use standard United Nations terminology in the interactive dialogue'. ${ }^{30}$ This then ended this topic of discussion. This brief exchange reveals how during the UPR process political tensions can inhibit constructive peer-to-peer discussion and limit scrutiny of a Member State's response to internal displacement, especially when the Member State under review is, either rightly or wrongly, implicated in its cause. While this is admittedly only a single example, this finding is corroborated by Patel, who, in the context of UPR discussions on female genital mutilation (FGM), identifies an overt defensiveness from States under review, ${ }^{31}$ which Patel argues is indicative of a more general failure to consistently protect 'the universality of all human rights norms... in relation to all human rights issues and concerns' ${ }^{32}$

\subsection{The UPR's potential}

There are some significant advantages to the UPR process as a forum for exchange and scrutiny of internal displacement matters. The UPR is a global human rights forum that brings together all Member States, without exception, as equal partners. The expectation is that all States participate, as both reviewer and reviewee. This reflects the global nature of internal displacement. It means that any State can be questioned on internal displacement within its borders. Moreover, it only takes one Member State to raise internal displacement as an issue to get this onto the agenda, and thus elevate it as a matter of international human rights concern in a particular Member State. The UPR process is also transparent, especially when compared to many other global reporting frameworks. A record of questions, comments, recommendations and responses is made publicly available online for each Member State in each cycle.

Yet, the analysis presented here raises doubts as to the desirability and probable efficacy of an expanded role for the UPR in the global peer-to-peer dialogue on internal displacement. While theoretically any Member State can be scrutinised in respect to internal displacement, the evidence indicates that this does not presently happen in practice. Indeed, whether or not such

\footnotetext{
${ }^{30}$ Report of the Working Group on the Universal Periodic Review - Syrian Arab Republic, 27 December 2016, $\mathrm{A} / \mathrm{HRC} / 34 / 5$, para. 24.

${ }^{31}$ G. Patel, "How "Universal" is the United Nations' Universal Periodic Review? An Examination of the Discussions held on Female Genital Mutilation in the First Cycle of Review", Intercultural Human Rights Law Review, 12, 2017, 187-226, 221.

${ }^{32}$ G. Patel, "How "Universal" is the United Nations' Universal Periodic Review? An Examination of the Discussions held on Female Genital Mutilation in the First Cycle of Review", Intercultural Human Rights Law Review, 12, 2017, 187-226, 222.
} 
discussion occurs depends upon the political will to raise, and continue to raise, internal displacement as a substantive topic during the UPR process. In respect to transparency, while this is typically viewed as being of value in and of itself, it is not necessarily conducive to the raising of contentious issues, such as internal displacement, in a public arena. Moreover, even when internal displacement is raised, diplomatic expediency might inhibit the type of candid discussions needed for effective scrutiny. Time is also an issue. The UPR process is necessarily time limited ${ }^{33}$ and the multiplicity of issues means that internal displacement can become lost or downplayed, or can be too easily swept aside or disregarded by a Member State unwilling to face scrutiny on such matters. Also in respect to time, reviews are conducted only once every four years, meaning the UPR is not suited to rapid response, nor to the monitoring of specific individual human rights issues within a State unless such issues are lengthy or protracted. ${ }^{34}$ This can then further compounded by delays in the reporting process itself.

It may be possible to alleviate some of these concerns by developing a method of working through which internal displacement is raised in a more systematic manner within the UPR process, for example, by establishing it as a standing issue. This would ensure that internal displacement is firmly on the agenda. ${ }^{35}$ However, this would not deal with a more fundamental conceptual concern that arises from internal displacement being a cross-cutting issue. As explained above, internal displacement is cross-cutting in the sense that it engages innumerable individual human rights. Yet, it is also widely accepted that internal displacement is crosscutting in the sense that it is intrinsically linked to not only human rights, but also, inter alia, humanitarian, peacebuilding, development, and disaster risk management and prevention concerns. This latter understanding of internal displacement as cross-cutting is too easily lost in a forum that is exclusively dedicated to human rights concerns. Effective dialogue and holistic scrutiny of internal displacement demands the existence of a forum where all facets of

\footnotetext{
${ }^{33}$ As Higgins observes, 'The tight time constraints have sometimes resulted in a lack of critique of States' human rights records', see N. Higgins, "Advancing the Rights of Minorities and Indigenous Peoples: Getting UN Attention via the Universal Periodic Review", Netherlands Quarterly of Human Rights, 32(4), 2014, 379-407, 388. The concerns around this are then compounded by Sweeney's and Saito's finding of filibustering by States allied to the State under review $(2009,210)$.

${ }^{34}$ N. Higgins, "Advancing the Rights of Minorities and Indigenous Peoples: Getting UN Attention via the Universal Periodic Review", Netherlands Quarterly of Human Rights, 32(4), 2014, 379-407, 403.

${ }^{35}$ Yet, by itself, establishing internal displacement as a standing item would do little to tackle the experience of muted questioning or evasive responses. It would also demand a fundamental change in the way in which matters are raised within the UPR process, a change that would in fact signal a return to an approach deemed ineffective during the time of the now-defunct, and much-maligned, UN Commission on Human Rights. Moreover, it would inevitably (due to time limitations) pit internal displacement against other matters that are similarly deserving of such privileged attention, and risk side-lining some such other issues.
} 
the phenomenon can be given due consideration, where discussion and action is not stifled by siloed ways of thinking and working. The UPR is a global catch-all human rights forum, yet it is still evidently ill-equipped to adequately address a cross-cutting issue of such global importance.

\section{REFUGEE PROTECTION FORA}

IDPs are similar to refugees in many ways. IDPs often have similar wants, fears, and needs as refugees. They often flee for the same or very similar reasons such as conflict and/or human rights violations. Some IDPs go on to cross a border and become refugees, and some refugees return to their countries of nationality and become IDPs. Often IDPs and refugees live side by side, especially where displacement straddles a border. ${ }^{36}$ In addition, some organisations such as the UNHCR are involved in both IDP and refugee response. ${ }^{37}$ As such, many fora that consider issues relating to refugee response also consider IDP response issues. This section will deal with two fora which are tasked primarily with refugee response: the Executive Committee of the UNHCR (EXCOM) and the Global Compact on Refugees (GCR). The potential of each forum as a means for drawing attention to IDP issues will first be considered before examining whether any of these for a might serve as models for creating similar kinds of global fora for internal displacement.

\subsection{The Executive Committee of the High Commissioner's Programme (EXCOM)}

The UNHCR's primary mandate is refugee protection and facilitating solutions to the refugee problem. ${ }^{38}$ However, it has been involved in IDP response since the $1970 \mathrm{~s} .{ }^{39}$ Its most recent

\footnotetext{
${ }^{36}$ B. Ní Ghráinne, Internally Displaced Persons and International Refugee Law, Oxford, Oxford University Press, 2021 (forthcoming).

37 B. Ní Ghráinne, "UNHCR's Involvement with IDPs - 'Protection of that Country' for the Purposes of Precluding Application of the Refugee Convention?" International Journal of Refugee Law, 27(1), 2015, 536554.

38 UN General Assembly, Statute of the Office of the United Nations High Commissioner for Refugees, 14 December 1950, A/RES/428(V),

39 There has been significant debate on the benefits and pitfalls of UNHCR's involvement with IDPs. See R. Plender, "The Legal Basis of International Jurisdiction to Act with Regard to the Internally Displaced", International Journal of Refugee Law, 6(3), 1994, 345-361; G.S. Goodwin-Gill, "Refugee Identity and Protection's Fading Prospect", in F. Nicholson and P. Twomey (eds.), Refugee Rights and Realities: Evolving Concepts and Regimes, Cambridge, Cambridge University Press, Cambridge, 1999, 220-249; C. Phuong, "The Office of the United Nations High Commissioner for Refugees and Internally Displaced Persons", Refugee Survey Quarterly, 24(3), 2005, 71-83; C. Phuong, "Improving the United Nations Response to Crises of Internal Displacement", International Journal of Refugee Law, 13(4), 2001, 491-517; G.S. Goodwin-Gill, "UNHCR and Internal Displacement: Stepping into a Legal and Political Minefield”, in U.S. Committee for Refugees (USCR)
} 
Strategic Directions 2017-2021 document commits UNHCR to leveraging fully the synergies between their engagement with refugees and other categories of persons of concern, including IDPs. ${ }^{40}$ In particular, UNHCR has committed to be more predictable and decisive in situations of internal displacement. ${ }^{41}$ It has also recently launched an 'Initiative on Internal Displacement'. This aims to generate examples of good practices, give greater visibility to the impact of internal displacement on those affected, secure more resources for IDP responses, and strengthen its support to operations in nine target countries. ${ }^{42}$

One way to feed into UNHCR's policy vis-à-vis IDPs is through EXCOM. EXCOM's membership is limited to UN Member States or members of any of the specialised agencies. It meets in Geneva annually to review and approve the UNCHR's programmes and budget, authorise the High Commissioner to make appeals for funds, advise on international protection, and discuss a range of other issues with UNHCR and intergovernmental and non-governmental partners. It also holds additional meetings throughout the year. ${ }^{43}$ However, UNHCR's

(ed.), World Refugee Survey 2000, Washington D.C., USCR, 2000; R. Cohen, "Strengthening Protection of IDPs: the UN's Role", Georgetown Journal of International Affairs, 2006, 101-109; R. Cohen, "Developing an International System for Internally Displaced Persons", International Studies Perspectives, 7, 2006, 87-101; M. Bradley, 'Unintended Consequences of Adjacency Claims: The Function and Dysfunction of Analogies between Refugee Protection and IDP Protection in the Work of UNHCR', Global Governance, 25(4), 2019, 620-644; D. Lanz, "Subversion or Reinvention? Dilemmas and Debates in the Context of UNHCR's Increasing Involvement with IDPs", Journal of Refugee Studies, 21(2), 2008, 192-209; M. Barutciski, "A Critical View on UNHCR's Mandate Dilemmas", International Journal of Refugee Law, 14(2-3), 2002, 365-381; M. Barutciski, "The Reinforcement of Non-Admission Policies and the Subversion of UNHCR: Displacement and Internal Assistance in Bosnia-Herzegovina, 1992-1994", International Journal of Refugee Law, 8(1-2), 1996, 49-110; E. Feller, "UNHCR's Role in IDP Protection: Opportunities and Challenges", Forced Migration Review, Special Issue, 2006, 11-13; E.D. Mooney, "In-Country Protection: Out of Bounds for UNHCR?, in F. Nicholson and P. Twomey (eds.), Refugee Rights and Realities: Evolving Concepts and Regimes, Cambridge University Press, Cambridge, 1999, 200-219; UNHCR, "Operational Review of UNHCR's Engagement in Situations of Internal Displacement", International Journal of Refugee Law, 32(2), 2018, 373-391; L. Aubin, E. Eyster \& D. Macguire, "People-Centred Principles: The Participation of IDPs and the Guiding Principles", International Journal of Refugee Law, 30(2), 2018, 287-291; G.S. Goodwin-Gill, "International Protection and Assistance for Refugees and the Displaced: Institutional Challenges and United Nations Reform", Workshop on Refugee Protection in International Law, Oxford, 2006; B. Ní Ghráinne, "UNHCR's Involvement with IDPs - 'Protection of that Country' for the Purposes of Precluding Application of the Refugee Convention?" International Journal of Refugee Law, 27(1), 2015, 536554.

${ }^{40}$ United Nations High Commissioner for Refugees (UNHCR), UNHCR's Strategic Directions 2017-2021, Geneva, UNHCR, 2017, available at: https://www.unhcr.org/5894558d4.pdf (last visited 28 July 2020).

${ }^{41}$ United Nations High Commissioner for Refugees (UNHCR), Policy on UNHCR's Engagement in Situatoins of Internal Displacement, Geneva, UNHCR, 2019, available at:

https://www.refworld.org/pdfid/5d83364a4.pdf (last visited 28 July 2020).

${ }^{42}$ United Nations High Commissioner for Refugees (UNHCR), UNHCR's Initiative on Internal Displacement 2020-2021, Geneva, UNHCR, available at:

reporting.unhcr.org/sites/default/files/UNHCR\%20Initiative\%20on\%20Internal\%20Displacement\%202020-

2021.pdf\#_ga=2.75539037.972452552.1592461531-923638272.1555054360 (last visited 28 July 2020).

${ }^{43}$ For a schedule of upcoming meetings see United Nations High Commissioner for Refugees (UNHCR), Upcoming Meetings, available at:

www.unhcr.org/excom/orginfo/5c4730614/70th-calendar-of-upcoming-meetings.html (last visited 28 July 2020). 
operations in respect of IDPs is limited: first, by its mandate (which focuses on refugee response); second, by the fact that its IDP efforts mainly relate to conflict-induced displacement; and third, by the fact that its IDP efforts must be carried out as part of the cluster system of IDP response, which involves many other UN agencies and NGOs. These limitations will in turn affect how EXCOM can address IDP response issues.

\subsection{Global Compact on Refugees}

The New York Declaration for Refugees and Migrants is a political commitment, adopted in 2016, which contains a wide range of commitments by States to strengthen and enhance mechanisms to protect people on the move. ${ }^{44}$ It paved the way for the adoption of two new global compacts in 2018, one of which was the Global Compact on Refugees (GCR). ${ }^{45}$ The GCR is not directed at IDP response specifically. In fact, it has been criticised for 'virtually' ignoring IDPs. ${ }^{46}$ However, one of the GCR's key objectives is to support conditions in countries of origin for return in safety and dignity. ${ }^{47}$ It also notes that population movements may be of a composite character and may involve IDPs. ${ }^{48}$ In addition, it directs States to 'take into account' the situation of IDPs when contributing resources and expertise to support countries of origin. ${ }^{49}$ As such, IDP response issues should be a key consideration when implementing the GCR and there are a number of ways in which to raise IDP issues within the GCR framework.

\subsubsection{Global Refugee Forum}

\footnotetext{
${ }^{44}$ United Nations High Commissioner for Refugees (UNHCR), New York Declaration for Refugees and Migrants, Geneva, UNHCR, 2016, available at: https://www.unhcr.org/new-york-declaration-for-refugees-and-migrants.html (last visited 28 July 2020).

45 United Nations High Commissioner for Refugees (UNHCR), The Global Compact on Refugees, Geneva, UNHCR, 2018, available at: https://www.unhcr.org/the-global-compact-on-refugees.html (last visited 28 July 2020).

${ }^{46}$ E. Ferris and S. Martin, "The Global Compacts on Refugees and for Safe, Orderly and Regular Migration: Introduction to the Special Issue", International Migration, 57(6), 2019, 5-8. See also T. Alexander Aleinikoff, "The Unfinished Work of the Global Compact on Refugees", International Journal of Refugee Law, 30(4), 2018, 611- 617; A. dos Santos, "The (Un)Protection of Internally Displaced Persons under the Global Compact on Refugees" in C. Lazarski, J.García Cívico and A.Sungurov, (eds) Current Issues on Human Rights, Dykinson, 2020, 289-300.

${ }^{47}$ United Nations High Commissioner for Refugees (UNHCR), The Global Compact on Refugees, Geneva, UNHCR, 2018, available at: https://www.unhcr.org/the-global-compact-on-refugees.html (last visited 28 July 2020).

48 Para 12.

49 Para 89
} 
A central arrangement of the GCR is the Global Refugee Forum (GRF), where States and other actors come together every four years to share good practices and contribute with financial support, technical expertise, and policy changes to help achieve the goals of the GCR. ${ }^{50}$ The first GCR took place in December 2019. ${ }^{51}$ IDP-related good practices from last year's forum include:

- a German-led programme in 13 partner countries creating economic and social prospects for refugees who are returning to their home countries, IDPs, and the local population; ${ }^{52}$

- a programme led by RET international which provides holistic socio-economic empowerment training to refugee and local women (including IDPs) in Turkey and several LAC countries; ${ }^{53}$ and

- a programme by Water 4 and its local enterprise partner AEDR to drill wells to benefit the lives of IDPs in the DRC. ${ }^{54}$

The next GRF will take place in 2023, with a mid-term review meeting in 2021. One advantage of the GRF is that there is a huge number and range of attendees, and it is not limited to States: in 2019, there were 3,000 participants including heads of State, NGOs, ministers UNSG, representatives of international organisations and UN agencies/bodies, companies/foundations, and civil society organisations. As such it provides a high level and very broad platform to raise awareness of IDP issues (insofar as they relate to refugee issues). However, IDP issues have not been widely discussed at the GRF. Although - as aforementioned - some IDP-related good practices were shared, no state made any pledge relating to IDPs. This suggests that the GCR might not be particularly receptive to further input on IDP issues.

\footnotetext{
${ }^{50}$ United Nations High Commissioner for Refugees (UNHCR), Global Refugee Forum, UNHCR, available at: https://www.unhcr.org/global-refugee-forum.html (last visited 28 July 2020).

${ }^{51}$ United Nations High Commissioner for Refugees (UNHCR), Pledges and Contributions Dashboard, UNHCR, available at: https://globalcompactrefugees.org/channel/pledges-contributionsexcex (last visited 28 July 2020).

${ }^{52}$ United Nations High Commissioner for Refugees (UNHCR), Creating opportunities for displaced people returning home, UNHCR, 2020, available at: https://globalcompactrefugees.org/article/creating-opportunitiesdisplaced-people-returning-home (last visited 28 July 2020).

${ }^{53}$ United Nations High Commissioner for Refugees (UNHCR), Women-led livelihood training in crises affected contexts, available at: https://globalcompactrefugees.org/index.php/article/women-led-livelihood-training-crisisaffected-contexts (last visited 28 July 2020).

${ }^{54}$ United Nations High Commissioner for Refugees (UNHCR), Women-led livelihood training in crises affected contexts, available at: https://globalcompactrefugees.org/index.php/article/women-led-livelihood-training-crisisaffected-contexts (last visited 28 July 2020).
} 


\subsubsection{The Comprehensive Regional Protection and Solutions Framework}

Recognising the need for a more equitable and predictable global approach to large scale displacement, Annex 1 of the New York Declaration called for the development of a Comprehensive Refugee Response Framework (CRRF). ${ }^{55}$ The 'Comprehensive Regional Protection and Solutions Framework' (MIRPS, for its acronym in Spanish) is the regional, practical and detailed application of the CRRF in Central and North America. The MIRPS is made up of seven States - Belize, Costa Rica, El Salvador, Guatemala, Honduras, Mexico and Panama. It seeks to galvanise new commitments and operationalise existing ones to address forced displacement from a wholly regional perspective, incorporating countries of origin, destination and transit, and working with a wide range of stakeholders to create a truly comprehensive and sustainable approach. The MIRPS has an operational schedule that initially runs from 2018 to $2020 .^{56}$

Guided by the New York Declaration and the CRRF, the mandate of MIRPS is primarily directed towards refugees. However, it has considered IDP issues as part of its refugee mandate. For example, one of its priority areas is to enhance opportunities for durable solutions. In addressing this priority, Honduras included the category of causing internal displacement within the new draft Penal Code. In addition, various national institutes in Honduras formed a working group with the aim of enhancing knowledge on the protection of land and housing in the context of internal forced displacement in Honduras.

The MIRPS offers a number of peer-to-peer fora where IDP issues can be raised as part of the discussion surrounding refugee response. It has a rotating presidency, which provides a forum for the articulation of strategic actions and new initiatives to address forced displacement and international protection needs from a regional and human rights approach. The presidency holds dialogues within the framework of online and high level in-person meetings among MIRPS countries, Resident Coordinators of the United Nations, and with cooperating and donor countries, among other partners, on issues related to emergencies, on current challenges

\footnotetext{
${ }^{55}$ Comprehensive Regional Protection and Solutions Framework (MIRPS), Concept Note: Regional Conference in San Pedro Sula as a follow up of the New York Declaration "Comprehensive Regional Protection and Solutions Framework”, MIRPS, San Pedro Sula, 2017, available at: https://www.mirps-hn.org/en/concept-note/ (last visited 28 July 2020).

${ }^{56}$ Comprehensive Regional Protection and Solutions Framework (MIRPS), Comprehensive Regional Protection and Solutions Framework: Regional Annual Report 2017-2018, MIRPS, available at: https://www.acnur.org/5be46d904.pdf_(last visited 28 July 2020).
} 
in the search of comprehensive solutions. A working group on IDPs has also been established, which will convene three workshops on IDP issues.

\subsection{Creating an IDP Response Forum?}

Some scholars have suggested that a new platform for IDP response should be created, inspired by refugee fora such as the GCR process. For example, Alienikoff sees potential to harness the language of the New York Declaration, which notes 'the need for reflection on effective strategies to ensure adequate response and assistance for internally displaced persons and to prevent and reduce such displacement' ${ }^{57}$ Aleinikoff argues that the New York Declaration sets out the duly registered will of the UN General Assembly, and consistent with that will would be the establishment of a UN process for consideration of the plight and needs of the more than 40 million displaced persons. Ferris and Martin suggest, inter alia, a UN Special Representative for IDPs, or a comprehensive study or Summit on IDPs. ${ }^{58}$

Although these suggestions are welcome, it is unlikely that there is sufficient political will to develop an initiative for IDPs similar to those that have been created for refugees. The main idea behind the GCR is solidarity and sharing responsibility for the global refugee population. As IDPs do not cross a border, their protection is often seen as a domestic issue and less dependent on international cooperation. In fact, the difficulties in generating political will in respect of refugee response might even be multiplied in the IDP context, as international engagement with IDPs continues to be perceived as intervention into the internal affairs of a state. ${ }^{59}$ Moreover, the lack of reference to internal displacement in the GCR as well as the lack of any formal IDP forum to date might be indicative of the lack of priority given to to the IDP issue by governments.

There are also a number of more general issues that have been raised with the GCR that should be noted when it is being considered as a model for potential IDP response fora. First, the GCR was negotiated against the backdrop of major political constraint, nationalism, and anti-

\footnotetext{
57 Para 20. See T. Alexander Aleinikoff, "The Unfinished Work of the Global Compact on Refugees", International Journal of Refugee Law, 30(4), 2018, 611- 617.

${ }^{58}$ E. Ferris and S. Martin, "The Global Compacts on Refugees and for Safe, Orderly and Regular Migration: Introduction to the Special Issue", International Migration, 57(6), 2019, 5-8.

${ }^{59}$ E. Ferris and S. Martin, "The Global Compacts on Refugees and for Safe, Orderly and Regular Migration: Introduction to the Special Issue", International Migration, 57(6), 2019, 5-8.
} 
immigrant rhetoric. ${ }^{60}$ This has led many to criticise the GCR for not going far enough and for not addressing key issues such as the role of western states in causing displacement and state practices of refugee containment and deterrence. ${ }^{61}$ The development of any potential IDP forum would face a similar anti-migrant political background and as such, a future IDP forum might also evade dealing with key controversial issues such as the responsibilities of states for causing displacement. Moreover, the approach of the GCR is global in nature which might be an advantage in the IDP context when considering the global reach of the IDP problem, but it is not necessarily suited to tackling regional problems. Creating regional IDP fora - similar to the MIRPS - might be one way to address this issue. Finally, careful consideration should be given to which actor should lead any future IDP forum. For example, the UNHCR has a monitoring role in the GCR but its independence might be constrained by its reliance on voluntary funding by states. ${ }^{62}$ As such, the GCR may not be a very good model for a potential IDP response forum both because of UNHCR's perceived potential lack of impartiality and because of the fact that it does not have a primary mandate for IDP response.

\section{INTERNAL DISPLACEMENT-SPECIFIC PLATFORMS}

In contrast to the global infrastructure built around the issue of refugee movements, there is no formal State-based forum at the global level specifically dedicated to internal displacement. However, in recent years, there have been notable efforts to initiate more ad-hoc, informal channels through which inter-State dialogue on internal displacement is promoted. Unlike the UN and refugee-focused platforms already discussed, these new initiatives are targeted exclusively towards the issue of internal displacement. Most notable among these are the GP20 and the IDMC-IOM Displacement Dialogues.

\subsection{GP20}

\footnotetext{
${ }^{60}$ E. Ferris and S. Martin, "The Global Compacts on Refugees and for Safe, Orderly and Regular Migration: Introduction to the Special Issue", International Migration, 57(6), 2019, 5-8; A. Betts, "The Global Compact on Refugees: Towards a Theory of Change?", International Journal of Refugee Law, 30(4), 2018, 623-626.

${ }^{61}$ B.S. Chimni, "Global Compact on Refugees: One Step Forward, Two Steps Back", International Journal of Refugee Law, 30(4), 2018, 630-634; M. Ineli-Cigur, "The Global Compact on Refugees and Burden Sharing: Will the Compact Address the Normative Gap Concerning Burden Sharing?" Refugee Survey Quarterly, 38, 115-138; J. Hathaway, "The Global Cop-Out on Refugees", International Journal of Refugee Law, 30(4), 2018, 591-604; T. Alexander Aleinikoff, "The Unfinished Work of the Global Compact on Refugees", International Journal of Refugee Law, 30(4), 2018, 611- 617.

62 B.S. Chimni, "Global Compact on Refugees: One Step Forward, Two Steps Back", International Journal of Refugee Law, 30(4), 2018, 630-634.
} 
The GP20 was initiated in the first half of 2018 to mark the twentieth anniversary of the 1998 UN Guiding Principles on Internal Displacement. ${ }^{63}$ It is a three-year, multi-stakeholder endeavour, spearheaded by the UN Special Rapporteur on the Human Rights of IDPs, the UNHCR and the UN Office for the Coordination of Humanitarian Affairs (OCHA). A Steering Group, co-chaired by the UNHCR and UN OCHA, ${ }^{64}$ is responsible for overseeing the implementation of 'A Plan of Action for Advancing Prevention, Protection and Solutions for Internally Displaced People 2018-2020' ${ }^{65}$ The overarching goal of the Plan of Action is ambitious - 'to reduce and resolve internal displacement through prevention, protection and solutions for IDPs' ${ }^{66}$ The Plan of Action is underpinned by four core 'priorities for change' that form the basis of four main objectives. These are to:

- strengthen IDP participation in the decisions that affect them;

- expand the development and implementation of national laws and policies on internal displacement;

- increase capacity for data and analysis on internal displacement; and

- address protracted displacement and support solutions, including by scaling up States' lead role in this respect. ${ }^{67}$

These are of course all laudable objectives. Nonetheless, it is immediately clear that the GP20 has a very broad remit, especially given the fact that the Plan of Action is only scheduled to run until the end of 2020 .

Although there is no explicit mention of inter-State dialogue in any of the abovementioned objectives, the GP20 has to an extent helped catalyse such activity. Most notably, there have to date been two regional 'State-to-State exchanges' co-convened by the GP20 initiative, both

\footnotetext{
${ }^{63}$ Pursuant to a call by the UN General Assembly 'to mark the twentieth anniversary of the Guiding Principles on Internal Displacement so as to further demonstrate and strengthen collaboration on practices in addressing the challenges of internal displacement' (UN General Assembly, 'Protection of and Assistance to Internally Displaced Persons', 14 November 2017, A/C.3/72/L.46/Rev.1, para. 9).

${ }^{64}$ The Steering Group's Terms of Reference, dated 31 May 2018, are available at: https://www.globalprotectioncluster.org/_assets/files/20180531-tor-gp20-steering-group-final-_-june-2018.pdf (last visited 3 Aug. 2020).

${ }^{65}$ The full text of the Plan of Action is available at: https://www.globalprotectioncluster.org/_assets/files/20180523-gp20-plan-of-action-final.pdf(last visited 3 Aug. 2020).

${ }^{66}$ GP20 Plan of Action, 4.

${ }^{67}$ GP20 Plan of Action, 4.
} 
of which have taken place in Africa. The first was in March 2019 in Dakar, Senegal. The twoday 'West Africa Regional Exchange on Law and Policy to Prevent and Address Internal Displacement' brought together Members of Parliament (MPs) and national IDP experts from the fifteen Member States of the Economic Community of West African States (ECOWAS). ${ }^{68}$ This regional exchange focused on the sharing of experiences, including good practices and challenges, in respect to the domestication and implementation of the Kampala Convention. ${ }^{69}$ The second took place in Addis Abeba, Ethiopia, in October 2019. Co-convened by the GP20 and the Intergovernmental Authority on Development (IGAD), this exchange sought to 'take stock, draw lessons and document practices on supporting resilience and protection of IDPs and achieving durable solutions to internal displacement' ${ }^{70}$ It was attended by, inter alia, IGAD Member States, UN agencies, NGOs and academics. It too was a space for stakeholders to share experiences, good practices, challenges and recommendations in respect to preventing, addressing and resolving internal displacement. ${ }^{71}$ In the words of GP20, 'The preliminary recommendations were progressive and demonstrate a readiness amongst member states to take concrete steps to address internal displacement' ${ }^{72}$ Follow-up meetings to both of these regional exchanges are planned for the purposes of reviewing the recommendations made and continuing experience sharing among States affected by internal displacement in these two regions of Northern/Sub-Saharan Africa.

\subsection{IDMC-IOM Displacement Dialogues}

The Internal Displacement Monitoring Centre (IDMC) has, in partnership with the International Organisation for Migration (IOM), instituted a series of 'Displacement Dialogues'. These are State-based, ambassadorial level discussions of global aspiration that take place outside the structure of any formal international organisation. The Dialogues recognise that 'Member States' perspectives and priorities will help shape the formulation of

\footnotetext{
${ }^{68}$ GP20-ECOWAS, 'Comparative Experiences on Implementing the Kampala Convention', 21-22 March 2019, available at:

https://www.globalprotectioncluster.org/wp-content/uploads/ECOWAS-Regional-Exchange_EN.pdf (last visited 3 Aug. 2020), 4.

${ }^{69}$ Ibid.

${ }^{70}$ GP20-IGAD, 'Comparative Experiences on Preventing, Addressing and Resolving Internal Displacement', 78 October 2009, available at: https://www.globalprotectioncluster.org/wp-content/uploads/IGAD-Regional-Exchange-report.pdf (last visited 3 Aug. 2020), 7.

${ }^{71}$ Ibid.

72 GP20, 'Newsletter August-October 2019', available at:

https://www.globalprotectioncluster.org/key-resources/ (last visited 3 Aug. 2020).
} 
future policies and global discussions on internal displacement. ${ }^{973}$ In essence, the Displacement Dialogues aim to generate increased political will among affected States to tackle the issue of internal displacement. ${ }^{74}$

The Dialogues provide a space where States affected by internal displacement can come together as fellow IDP-hosting countries to 'identify common challenges, share concerns and consider solutions'. ${ }^{75}$ Open dialogue and information sharing is encouraged, principally through the Dialogues being held under Chatham House rules and by being invitation only. ${ }^{76}$ In 2018, three Displacement Dialogues were held, bringing together Geneva-based ambassadors from sixteen States, ${ }^{77}$ 'to discuss issues such as development and long-term approaches to addressing displacement, the implications of the link between internal and crossborder movements, and the need for international coordination, financing and technical assistance' ${ }^{78}$ In 2019, the Displacement Dialogues continued, with four held in Geneva for a network of twenty ambassadors, ${ }^{79}$ covering topics such as urbanisation and the humanitariandevelopment nexus.

Interest in the Dialogues from ambassadors has been high. Since the first Dialogue in May 2018, the number of ambassadors attending has grown, more than doubling in size. While the majority of States attending have populations displaced by conflict and violence, there is nonetheless a healthy balance between these and States affected exclusively or predominantly by disaster-induced displacement, including Bangladesh, Fiji, Indonesia and Philippines.

The IDMC and IOM have committed to continue convening the Displacement Dialogues with interested States until 2023. ${ }^{80}$ To date, the Dialogues have primarily been about information

\footnotetext{
${ }^{73}$ IOM-IDMC, 'Global Partnership on Internal Displacement 2019-2023', available at: https://www.iom.int/sites/default/files/our_work/DOE/iom_idmc_global_partnership.pdf (last visited 30 July 2020), 5.

${ }^{74}$ Ibid.

75 Ibid.

76 IDMC, 'Annual Report 2018', available at: https://reliefweb.int/sites/reliefweb.int/files/resources/201906annual-report-2018.pdf (last visited 31 July 2020), 14.

77 This included Afghanistan, Azerbaijan, Burkina Faso, Chad, Colombia, Ethiopia, Fiji, Honduras, Indonesia, Iraq, Mali, Mexico, Niger, Nigeria, Philippines, and Ukraine.

78 IDMC, 'Annual Report 2018', available at: https://reliefweb.int/sites/reliefweb.int/files/resources/201906annual-report-2018.pdf (last visited 31 July 2020), 14.

${ }^{79}$ IDMC, '2019: IDMC at a Glance', available at:

https://www.internal-displacement.org/sites/default/files/publications/documents/2019_IDMC_ataglance.pdf (last visited 31 July 2020), 2.

${ }^{80}$ IOM-IDMC, 'Global Partnership on Internal Displacement 2019-2023', available at:
} 
exchange, trust-building and general dialogue. Moving forward, the intention is to shift towards more sustained peer-to-peer dialogue and learning, especially around the sharing of best practice. Another aim is to engage more "non-traditional" IDP hosting-States in the Dialogues, as well as furthering the involvement of neighbouring non-IDP-hosting States that have an interest in the resolution of IDP crises in their regions.

\subsection{Prospects for Informal Platforms on Internal Displacement}

It is fascinating, and indeed telling, that informal platforms for State-to-State dialogue on internal displacement have arisen in the ever-apparent void left by the absence of a global interState forum dedicated to internal displacement. These platforms exhibit a shift away from much of the formality and structure associated with processes such as the UPR, by instead promoting more ad-hoc, thematic discussions driven not so much by the wants of the international community but by the needs of affected States. These platforms also evidence a downplaying of internal displacement as a predominantly human rights concern, thereby bypassing some of the acrimony that has come to characterise exchanges on compliance with human rights norms.

It is still too early to draw any concrete conclusions as to the success of the GP20 regional exchanges or the IDMC-IOM Displacement Dialogues. Moreover, it remains somewhat unclear how the success of these platforms is to be measured. Yet, there are indications that the Displacement Dialogues are providing a space that is conducive to candid discussion and the fostering of new partnerships between previously unacquainted States. It is, moreover, evident that both the Dialogues and the GP20 have value as channels for the discussion of internal displacement and the sharing of State practices, thus keeping internal displacement on the agenda. However, there are concerns. Sustainability is one such concern, perhaps most pressingly in respect to the GP20, which is scheduled to finish within the coming months. A similar concern is whether such informal forums can retain the essence of their "informality" as they grow and inevitably become more institutionalised. Relatedly, there is the very real risk of these platforms becoming politicised as they expand geographically. Indeed, only States between whom there is no animosity currently attend the Displacement Dialogues. It is thus unclear at present how the Dialogues can be effectively scaled-up to resemble anything like a

https://www.iom.int/sites/default/files/our_work/DOE/iom_idmc_global_partnership.pdf (last visited 30 July 2020), 5. The Displacement Dialogues have been temporarily paused during the period of the UN High Level Panel on Internal Displacement. 
global platform for inter-State dialogue. Similarly, it is difficult to imagine a GP20 regional exchange taking place in either Eastern Europe or the Caucasus anytime in the near future. A further concern is transparency. While with the UPR there are disadvantages associated with politically contentious issues being discussed in such a public forum, legitimate questions can be raised about the level of privacy afforded to States by the Displacement Dialogues being held under Chatham House rules. Outstanding questions also remain over whether the Dialogues can have sufficient impact when they are very much Geneva-centric.

\section{CONCLUSION}

This paper has assessed how existing fora are, and might be, harnessed as sites or models for the discussion of internal displacement at the global level. Although there are benefits to raising IDP issues through existing fora, such as bringing IDP issues to the attention of an international audience (GRF, EXCOM, UPR) and/or discussing IDP issues in a more informal way (GP20 and IDMC Displacement Dialogues), there are numerous limitations with these existing fora. For example, internal displacement is scarcely discussed at the UPR, even in respect to States with the highest IDP populations. Refugee fora, such as the GRF and EXCOM, only discuss IDP issues insofar as they relate to refugee issues. In respect to the more informal IDP-specific platforms of the GP20 and the Displacement Dialogues, while these have some distinct advantages, real questions remain about their design, longevity and scalability.

It is time for a specific forum on internal displacement, as States have much to share and to learn from one another. Although every displacement crisis is unique, most are driven by natural disaster, climate change, conflict, development and/or one or more of these factors. While every IDP's story will differ, many will face similar protection needs, such as shelter, food, water, sanitation and healthcare. It makes sense that there should be a designated global State-to-State IDP forum to share practices, both good and bad, and perhaps to establish interState cooperation in responding to displacement. The need for an IDP-specific forum is further underscored by the fact that we are now witnessing the highest number of IDPs on record, reaching over 45.7 million at the end of $2019 .{ }^{81}$ An IDP-specific forum would firmly, and

\footnotetext{
${ }^{81}$ United Nations High Commissioner for Refugees (UNHCR), Internally Displaced People, Geneva, UNHCR, available at: https://www.unhcr.org/internally-displaced-people.html (last visited 3 Aug. 2020).
} 
finally, put IDP protection issues on the international agenda, and might also provide a valuable opportunity to monitor how States are treating their IDPs.

The virtual absence of IDPs from the GCR and UPR is indicative of the lack of priority given to internal displacement by States. While this might ultimately make it unlikely that a dedicated global IDP-specific forum will be established, it is precisely for this reason that one is more important and more urgent than ever. 